\title{
The Interweaving of Talk and Text in a French Criminal Pretrial Hearing
}

\author{
Esther González Martínez. \\ Department of Sociology \\ Boston University
}

\begin{abstract}
In this article, I analyze the talk between a suspect and a prosecutor during a pretrial hearing within the framework of the French criminal procedure of comparution immédiate (immediate trial). In this hearing, according to the law, the prosecutor is supposed to verify the suspect's identity, inform the suspect of the charges against him or her, and write down the suspect's statements if he or she chooses to make any. ${ }^{1}$ However, most of this meeting is taken up by a prosecutor-led discussion during which interlocutors display accounts of the alleged facts, produce series of questions and answers, dispute issues related to the case, and formulate the suspect's statement in written form. I show that this statement, overseen carefully by the prosecutor, emerges through the interweaving of different sequential activities, with talk and text reflexively constituting one another, in a restrictive speech exchange system fitted to the prosecutor's institutional orientations mainly with respect to building the case against the suspect.
\end{abstract}

The French code of criminal procedure (Section 393) provides that during the hearing preliminary to a comparution immédiate (immediate court appearance or immediate trial), the prosecutor shall inform the sus-

\footnotetext{
This article was written as part of a postdoctoral research project funded by the Swiss National Science Foundation (Grant PA001-105069). I thank Martha Komter, organizer of the colloquium "From Talk to Text" (Amsterdam, May 12-13, 2004) and editor of this special issue. The comments of John Heritage, George Psathas, and Don Zimmerman as well as those from the participants of the colloquium and the members of the New England Language and Social Interaction Research Group have been extremely insightful. My gratitude goes especially to Sally Jacoby for her invaluable support in the writing of this article.

Correspondence should be sent to Esther González Martínez, Department of Sociology, Boston University, 96 Cummington Street, Boston, MA 02215. E-mail: esthergo@bu.edu
} 
pect of the charges against the suspect and take his or her statement if he or she so requests. ${ }^{2}$ However, throughout the collection of hearings I analyzed in this study, ${ }^{3}$ once the prosecutor has verified the suspect's identity, the prosecutor always initiates and largely leads a "discussion" during which the prosecutor invariably composes the suspect's "statement." This text of barely a few lines is typically formulated (sometimes aloud) by the prosecutor and entered by hand into the hearing record to be signed afterwards by both the prosecutor and the suspect. Written in the first person, the text is supposed to represent the suspect's statement regarding the charges formulated as if it was made by the suspect unaided and uninterrupted. It is highly unusual for this written statement to make any reference to the discussion through which the text was produced. ${ }^{4}$

Despite a continuity with the topic and practical aspects of the discussion-in which the prosecutor and the suspect elaborate what happenedthe written statement is not and cannot possibly be an exact record or summary of what was said and/or done during the discussion. As a paradigmatic example of a "docile record," the suspect's statement encodes the institutional situation from which it emerges and is oriented toward its subsequent use in an institutional context. Moreover, the text exhibits official compliance with the rules of judicial procedure and erases through its standardized form the particularities of its production. ${ }^{6}$

In what follows, the focus is neither on the completed written text itself nor on evaluating its conformity to the suspect's actual words but is instead on how the interlocutors concretely, sequentially, and endogenously, through their talk, produce the suspect's statement in situ. ${ }^{7}$ Adopting an ethnomethodological perspective, I describe the procedures by which the interlocutors organize their talk. I show that the prosecutor and the suspect reflexively constitute both the discussion and the written statement, each with its specific characteristics, through a plurality and entanglement of sequential activities.

\section{AN AMBIGUOUS JUDICIAL MEETING}

This study's empirical material is a collection of audio recordings and conversational transcripts of judicial hearings conducted by three different prosecutors at the Paris Courthouse (France). ${ }^{8}$ Each hearing lasts on average 7 min, during which a prosecutor and a suspect meet in an office ${ }^{9}$ in the 
presence of a police officer who remains silent. ${ }^{10}$ These hearings take place after the suspect is arrested, kept in custody, and transferred to the courthouse but before the suspect appears in the court where he or she will be tried. ${ }^{11}$ The charges in these cases-mainly immigration violations, theft, assault, burglary, drug offenses, and fraud - are punishable by a maximum imprisonment of 1 to 5 years. ${ }^{12}$ These hearings are held as part of the accelerated criminal procedure of comparution immédiate in which the defendant is usually tried in the days immediately following his arrest. ${ }^{13}$ In the French criminal system, an impartial magistrate (juge d'instruction) normally conducts an in-depth incriminatory and exculpatory investigation before deciding whether to send the case to trial. However, in some cases, the prosecutor may determine that there is no need for such an investigation because there is sufficiently strong evidence against the suspect (i.e., the suspect has been caught red-handed). ${ }^{14}$ The prosecutor may then opt to handle the case through the immediate trial procedure. In this type of procedure, the prosecutor, rather than the investigating magistrate, leads the examination of the case. After a very brief police investigation, the prosecutor goes through the case record, meets with the suspect, and decides at some point whether or not to send the suspect to an immediate trial. Although in very exceptional cases, the prosecutor may change his or her decision during the course of the hearing, in the study corpus, it appears that the decision has in fact been established prior to the meeting with the suspect. ${ }^{15}$

There is no official term in the French code of criminal procedure for the interview between the prosecutor and the suspect- "hearing" (audition) is the category used most frequently in legal texts. This extremely brief encounter, combining inquiry designed to uncover the "truth" with prosecution necessary for charging the suspect and submitting the case to court, has an ambiguous legal and institutional character. ${ }^{16}$ Although not legally an interrogation, the meeting between the prosecutor and the suspect goes beyond the official scope of notification and hearing (informing the suspect of the charges against him or her, listening to and recording his or her statement). In reality, the prosecutor first verifies the suspect's identity and then presents the charges, which initiates a discussion with the suspect regarding the facts of the case. During this discussion, the prosecutor composes and writes the suspect's statement onto the hearing record form. ${ }^{17}$ This document is then included in the file of the case, which the judges will examine during the trial. ${ }^{18}$ The focus of this study is the organi- 
zation of this discussion - the heart of the hearing encounter-which is ignored in legal texts.

\section{JUDICIAL WORK AND THE ORGANIZATION OF TALK}

The legal and institutional ambiguity of the meeting between the prosecutor and the suspect is constituted in and through the complex organization of the talk central to the production of the suspect's written statement. The main characteristic of the organization of the discussion is a plurality and entanglement of activities largely led by the prosecutor. Each activity is recognizable by a particular sequence type, which accomplishes specific "moves" in the elaboration of what happened. ${ }^{19}$ A plurality of activities occurs when interlocutors successively introduce several types of sequences in the course of a single discussion. Entanglement of activities occurs when interlocutors combine in one sequence elements of more than one activity. ${ }^{20}$

The plurality and entanglement of activities are produced through an asymmetrical speech exchange system characterized by a recurrent order, type, number, and distribution of turns. ${ }^{21}$ The distribution of speaking rights favors the prosecutor who, using a wider range of turn types than the suspect, initiates the different sequential activities that compose the discussion. Moreover, the interactional asymmetry includes the prosecutor producing the first part of the paired exchanges that constitute activities, not only selecting the design and topical direction of the prosecutor's turns but also shaping the design and topical direction of the suspect's turns. The result is that the prosecutor has invaluable resources to shape the facts of the case, both during the discussion and in the written statement. ${ }^{22}$

The plurality and entanglement of activities are instrumental in producing a hearing devoted officially to informing the suspect of the charges against him or her and writing down the suspect's voluntary statement and also to, in the space of a few minutes, examining the facts and building the case against the suspect. Complex and flexible, this recurrent conversational organization enables the hearing's various judicial dimensions to coexist, prevail over one another, and become more or less visible. It is this common organization across hearing encounters that accounts for the equally similar format of the suspect's written statement, which results across prosecutors, suspects, and offenses. The organization of talk during the discussion also supports the prosecutor's institutional orientations, ${ }^{23}$ enabling the prosecutor to achieve the various judicial dimensions of the 
hearing, to maintain focus on the issues to be adjudicated following the hearing, and especially to build the case against the suspect.

\section{ACCOMPLISHING THE PLURALITY AND ENTANGLEMENT OF ACTIVITIES}

The hearings between the prosecutor and the suspect are routinely segmented into three parts. In the initial phase, the interlocutors open the conversation and the prosecutor checks the details of the suspect's identity that are already written on the hearing record form. In the second and longest phase, the discussion, the prosecutor and suspect elaborate the facts of what happened. In the third and final phase, the interlocutors talk about what will happen after the hearing and then close the conversation. ${ }^{24}$ It is in the discussion phase that a plurality and entanglement of activities is observed. With regard to plurality, the discussion phase comprises four sequential activity types: presentation of charges + response, questions and answers, dispute, and writing the suspect's statement. Despite some internal organizational regularity - the discussion always starts with the presentation of the charges - these activities follow no strict order, may be produced more than once, or may sometimes be absent. ${ }^{25}$

In the first sequential activity type, the prosecutor informs the suspect of the legal charges against him or her and then gives the floor to the suspect for his or her response; "I am listening to you" is the typical formula that the prosecutor uses to elicit the suspect's response. ${ }^{26}$ Typically the suspect's response has two parts: In the first, the suspect displays his or her stance regarding the charges; in the second, the suspect elaborates his or her own presentation of the facts. This sequence produces the initial display of each interlocutor's orientation about what happened while conveying simultaneously many different paired actions (e.g., request for agreement—agreement/disagreement; accusation—confession/excuse/justification/mitigation ${ }^{27}$ ). Each part of the sequence is typically a multiunit turn often comprising talk organized as a story. ${ }^{28}$ An example of the first sequence activity type is displayed in Excerpt $1^{29}$ :

Excerpt 1 DF/P. 2-D. $62^{30}$ (English translation)

01 P.2: $\quad>$ so $<(0.9)$ what you are blamed for is (.) ((leafs through the

02 file)) er stealing a wa:llet,

03 (.)

04 S.62: not stolen at all 


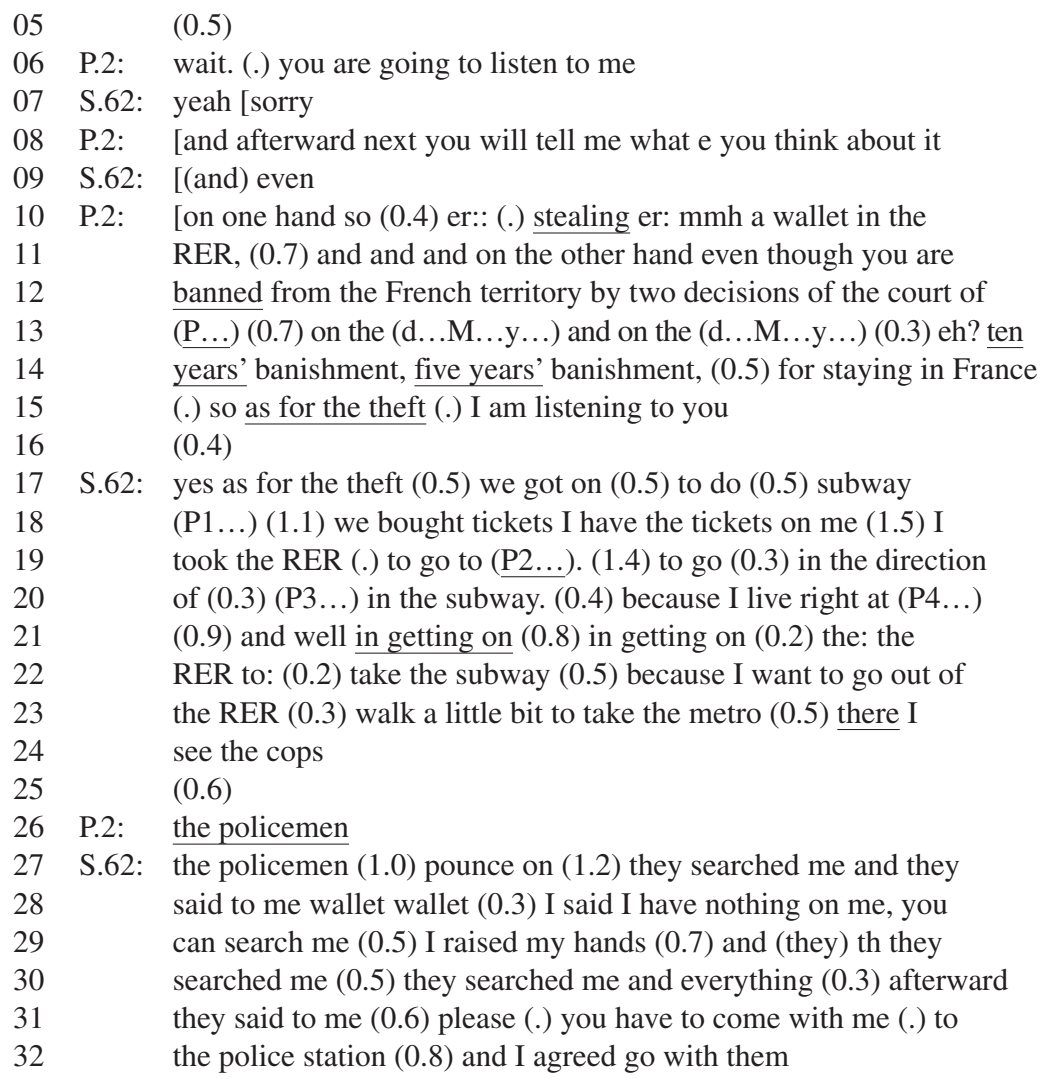

As can be seen in Excerpt 1, the prosecutor, P.2, presents the charges (lines $1-15)^{31}$ and then invites the suspect to talk about the theft (line 15). The suspect, S.62, who already in line 4 had said that he did not steal anything, now produces a story about his actions at the time the police arrested him (lines 17-32). During the course of this long turn, the prosecutor remains silent except to briefly correct the suspect's choice of words on one occasion (line 26). ${ }^{32}$

The second type of sequential activity is made up of a series of questions (asked only by the prosecutor) and answers from the suspect. ${ }^{33}$ Through this sequence, the interlocutors produce elements of the facts of the case that become part of a consistent description of what happened. Excerpt 2 is an example of this sequential activity type:

\section{Excerpt 2 DF/P. 2-D. 82 (English translation)}

01 P.2: [when you say we took the bag you were both together?,

$02 \quad(1.9)$


03 S.82: yes! him he took the bag me I was with him eh! (0.7) I was

04 outside but I saw him go o: there was there was the bag

$05 \quad$ (1.9)

06 P.2: and why did you steal?

$07 \quad(0.9)$

08 S.82: ${ }^{\circ}$ because it was reaching out to us. ${ }^{\circ}$

$09 \quad(1.1)$

10 P.2: ${ }^{\circ}$ it is too easy that is why?

11 S.82: ${ }^{\circ}$ yeah $^{\circ}(1.8)$ ((P.2 leafs through the file $\left.)\right)$ and on top of that er I have been out of trouble eh! for a long time eh

14 P.2: you broke the shop window?

15 S.82: no.

$16 \quad(1.5)$

17 P.2: and him?

$18 \quad(0.2)$

19 S.82: no. that I can confirm that to you eh

One can see in Excerpt 2 that the prosecutor asks a series of questions (lines $1,6,10,14,17$ ), each of which is answered by the suspect (lines $3-4,8,11$, $15,19)$. What is especially notable about this typical interrogative series is that as the suspect produces relevant answers to each question, the prosecutor moves the description of the facts along by producing a next question that is consistent with elements of the suspect's prior statements. It is in the third activity type that disputes emerge.

The third sequential activity type is a dispute comprised of a series of counterassertions that question aspects of what happened. ${ }^{34}$ In this dispute, the interlocutors produce, reformulate, and defend opposing orientations toward the facts. Excerpt 3 is an example of the dispute activity.

\section{Excerpt 3 DF/P. 1-D. 35 (English translation)}

01 P.1: he was not a policeman this gentleman you believed=

02 S.35: [I ( )

03 P.1: $=$ [that he worked (.) with the police but he was not a

04 policeman

05 S.35: no he is not a policeman but he works with them! [because

06 P.1: [(well) he works with (them) he says that eh?

07 S.35: no but I have: I was with him once (.) at the:: Cité (0.2) he

08 went inside me I stayed outside

09 P.1: everyone can go into the Cité: to look for papers or another

10 thing I mean you do not have to [( )

11 S.35: [but he has a card er business card which is written: the

12 telepho:ne number and sometimes he talks with a policeman on the

13 telephone 
14 P.1: you do not know who is on the other end of the line I mean this

15 policeman story he maybe made you believe that $>$ anyway $<$ it does

16 not matter $(\ldots)$

In Excerpt 3, the prosecutor questions the claim that the suspect's accomplice was a policeman or worked with the police (lines $1-4,6)$. The sequence turns into a dispute because both speakers, having uttered incompatible representations of the facts (the accomplice did[line 5]/did not work with the police [line 6]), maintain their views rather than abandoning them. The prosecutor and the suspect display incompatible representations regarding the meaning of entering the Cité (lines 7-8, 9-10) ${ }^{35}$ and of whether or not the accomplice telephoned a policeman (lines 11-13,14). This antagonistic exchange does not end until the prosecutor closes it down (lines 15-16).

The fourth sequential activity type is structured by the series of verbalizations made by the prosecutor as he is about to write, is writing, or has written elements of the suspect's statement. These verbalizations are always composed by the prosecutor but formulated in the first-person voice of the suspect. Each verbalization is typically followed by silence or responses from the suspect that acknowledge, agree with, or modify the prior first-person statement element. Excerpt 4 following is an example of this sequential activity type:

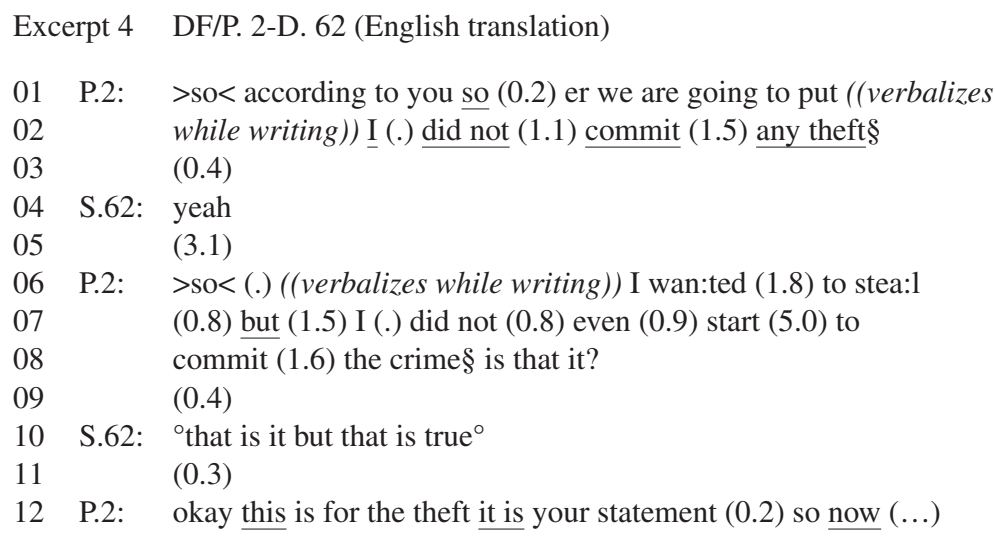

As excerpt 4 shows, the prosecutor verbalizes a first-person statement element while writing (line 2) and the suspect agrees (line 4). The prosecutor verbalizes a second 1st-person statement element (lines 6-8), asks the sus- 
pect "is that it?" (line 8), and the suspect agrees again (line 10). The prosecutor frames these exchanges with formulations that open (line 1) and close (line 12) the sequence. ${ }^{36}$

These examples of the four sequential activity types, which comprise the plurality of the prosecutor-suspect discussion, show the prosecutor leading the organization of the discussion. Among his numerous resources for accomplishing this are introducing and maintaining the various sequential activities using a large range of first-part turn types (presenting charges, asking questions, challenging assertions, and composing the written statement), thus initiating sequences that constrain the suspect responses.

With regard to entanglement, the prosecutor-suspect discussion is routinely organized through instances of these sequence types that the parties produce, abandon, suspend, expand, combine, or refract in any combination. Indeed, these four sequential activity types frequently interpenetrate one another. For instance, when the suspect is giving his response to the charges, the prosecutor may insert a question-answer sequence. In other instances, the interlocutors may simultaneously interweave two activities such as a question-answer sequence with the joint production of the written statement. ${ }^{37}$ Throughout the corpus, the plurality and entanglement of activities, firmly under the prosecutor's control, remain central organizational features that, as I examine next, play an essential role in shaping the written statement.

\section{THE INTERWEAVING OF TALK AND TEXT}

One important aspect of the discussion between the prosecutor and the suspect is the interweaving of talk with the writing of the suspect's statement. Sometimes, this written statement is produced in one compact and distinct sequence that summarizes the facts of the case mentioned in the discussion and that is oriented entirely toward the task of composition (see Excerpt 4 previously for an example). At other times, the prosecutor verbalizes only parts of the statement in progress and/or composes it throughout the discussion with the suspect without writing ever becoming the main activity. A third possibility is when the interlocutors interweave the writing of the suspect's statement with another sequential activity type, for instance, questioning.

I analyze Excerpt 5 following in detail as an example of this third possibility of accomplishing the writing task. Due to its length and complex 
structure, the excerpt is broken down into three parts (Excerpt 5a, Excerpt 5b, and Excerpt 5c). Excerpt 5a reproduces the last turn of the opening phase followed by the first activity of the discussion phase, the presentation of charges + response sequence. Excerpt $5 b$ shows a questioning sequence. Excerpt $5 \mathrm{c}$ reproduces the interweaving of the writing and questioning sequence. Following the interwoven sequence, the closing phase of the discussion encounter is initiated with the request to sign the hearing record form and explanation of what is going to happen after the meeting.

In Excerpt 5a, the prosecutor closes the identity-verification episode (of the hearing's opening phase) that had led the parties to examine the health problems that could prevent the suspect from working and initiates the discussion phase (line 5).

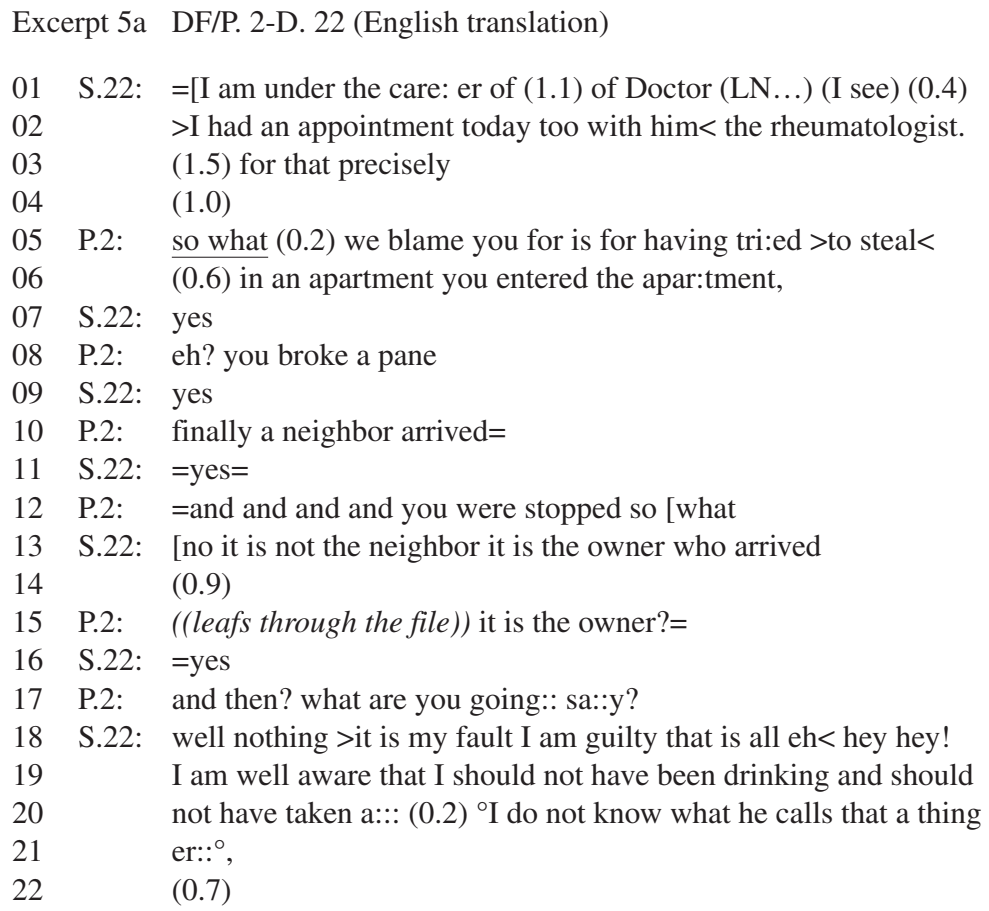

Typical of the beginning of the presentation of charges, the prosecutor produces the introductory formula "what we blame you for" 38 followed by the charge, marking the transition with a silence (line 4) and rising vocal volume (line 5). Again following a typical format, the prosecutor then 
details the facts of the case. In doing so, the prosecutor displays the first set of orientations toward what happened and identifies himself with them using the collective pronoun "we" (nous; line 5). This activity beginning is produced through a multiunit turn that the prosecutor delivers incrementally, allowing space for the suspect to respond to the various facts being recounted. Indeed, between some of the prosecutor's turn units, the suspect says "yes" (lines 7, 9, 11), ${ }^{39}$ which can be understood as much as a continuer as an agreement token. ${ }^{40}$ Except for his minimal responses, the suspect does not otherwise talk until the prosecutor reaches the moment of arrest in his narrative of what happened. At this point, the suspect produces a displaced correction of a detail that was said earlier ("no it is not the neighbor it is the owner who arrived" [line 13]). ${ }^{41}$ The suspect's correction introduces a repair sequence (lines 13-16) that briefly suspends the activity. ${ }^{42}$ The prosecutor then reinstates the charges + response activity by resuming what he was about to say before the correction ("and then what are you going say," line 17). ${ }^{43}$ This activity resumption gives the floor to the suspect that closes the first part of the sequence.

Excerpt 5a shows next the second part of the charges + response sequence (lines 18-22). The first part of the sequence (lines 5-17) functions as a preface that elicits and constrains the second part. On the prosecutor's invitation (line 17), the suspect begins to speak, displaying his own orientations toward the facts of the case. Now the prosecutor remains silent while the suspect produces his multiunit turn. Although the suspect's account is brief, it has the typical two parts. The first part sets the response in motion: The suspect displays his stance on what has just been said ("well nothing it is my fault I am guilty that is all, ..." line 18). In the second part, the suspect elaborates on his stance ("I am well aware that I should not have been drinking and should not have taken a, ..." lines 19-21). In this turn, the suspect reformulates what happened; he seems to accept the charges, an attitude perhaps foreshadowed by his repeating "yes" during the prosecutor's presentation, but he does not go back over the description of the acts ascribed to him. Instead, he declares that it is "my fault," that he is "guilty," and that he should not have been drinking or taking "a thing" he claims not to know how to name.

In Excerpt 5b, the prosecutor introduces a new activity (line 23) following the suspect's response. Now the interlocutors coconstruct a questioning sequence (lines 23-39) through which they produce elements of the facts of the case that constitute a consisting description of what happened: 


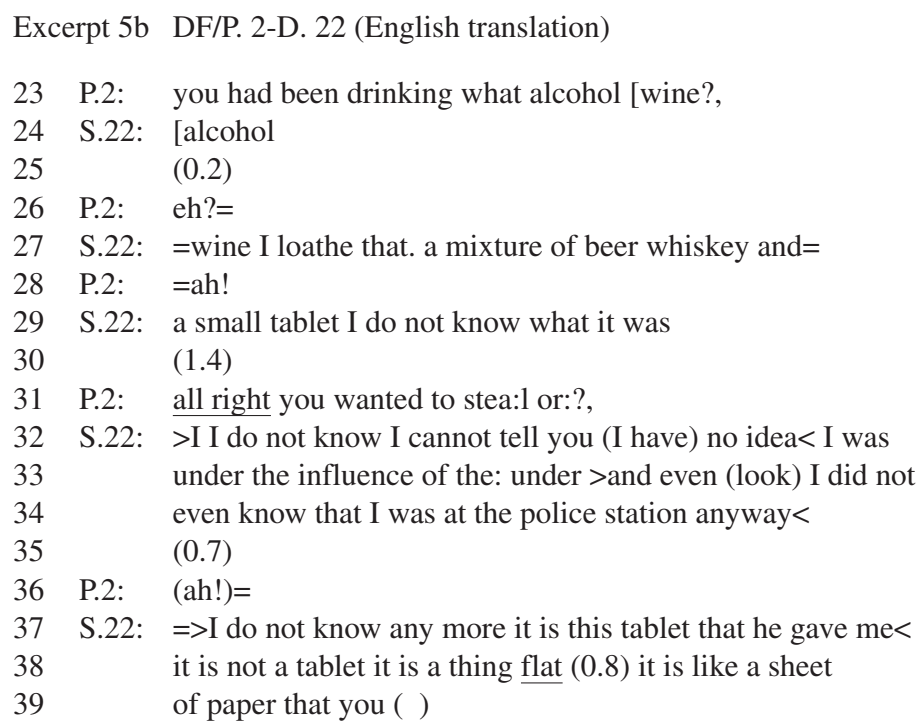

In line 23, the prosecutor transforms his turn in progress from an assertion to an open-ended question, finally suggesting two possible responses ("you had been drinking what alcohol wine"). In doing this, the prosecutor seems to have accepted the suspect's response to the charges (Excerpt 5a, lines 18-21) because he refers to an element the suspect had introduced (he had been drinking) and does not contest the suspect's answers. Indeed, in response to both the suspect's answers, the prosecutor exclaims "ah" (lines 28,36 ), indicating understanding mixed with surprise. The prosecutor then inquires as to the reason for the suspect to be in the premises, formulating a first possibility: "You wanted to steal or" (line 31). The suspect replies that he does not know what he wanted to do (line 32), referring again to his intoxicated state (lines 32-34) and the "thing" that he took (lines 37-39).

In Excerpt $5 \mathrm{c}$, the prosecutor next transitions to the activity of writing the suspect's statement:

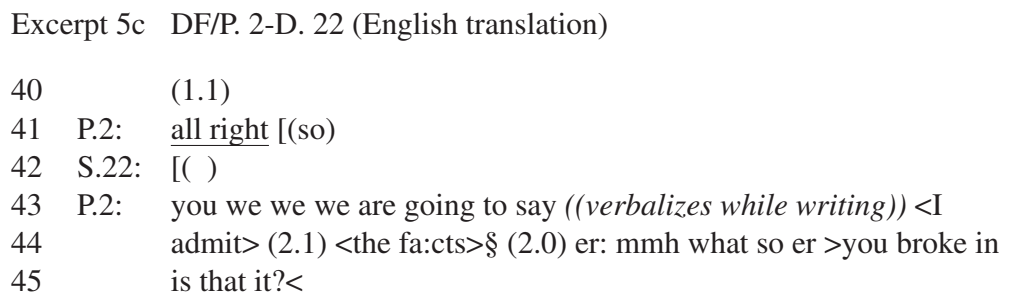


46 S.22: yes well apparently=

47 P.2: =you have $>$ what did you do break? $<=$

48 S.22: =well $>$ I smashed a pane according to what $<=$

49 P.2: $\quad=>$ you smashed a [pane eh?<

50 S.22: [(the man).

51 P.2: ((verbalizes while writing)) I (0.7) smashed (1.1) a pane $\S$

$52 \quad(0.5)$

53 S.22: I even told (er) Mister (LN...) I told (him) that I was willing to

54 pay for the pane if you want.

$55 \quad(0.5)$

56 P.2: $\quad>$ so< ((reads aloud)) I smashed a pane§ ((verbalizes while writing)) and $(0.3) \underline{I}$ ( .) entered (1.7) the (1.2) >apartment $<\S$ did you search around?

$60 \quad(1.1)$

61 P.2: $\quad[(($ verbalizes while writing $))$ I $(0.8)$ did not

62 S.22: [as soon as I saw that it was occupied (bam) ${ }^{\circ} \mathrm{I}$ wanted to leave ${ }^{\circ}$

63 P.2: searched (0.6) around $(1.7)>$ eh so ((reads aloud)) I admit the

S.22: yes=

67 P.2: $=$ and so then so you were stopped

$68 \quad(0.4)$

69 S.22: yes the owner (arrived)

$70 \quad(1.2)$

71 P.2: all right. (1.3) all right. so you admit (.) an attempted

72 theft? or you=

73 S.22: [no no

74 P.2: $=$ [admit a voluntary [damage?

75 S.22: [voluntary damage $=$

76 P.2: =so I am going to write it down eh=

77 S.22: =yes

$78 \quad(0.3)$

79 P.2: ((verbalizes while writing)) I would like (1.6) to specify (1.6)

$80 \quad$ that $(0.8)$ I $(0.6)$ do not confess (2.6) the attempted theft, (3.8)

81 I admit (2.2) the (0.2) voluntary damage $\S$

82 S.22: yes

$83 \quad(1.6)$

84 P.2: you were drunk is that it?

85 S.22: drunk and under the effect of a I do not know any more what they

$86 \quad$ call that

$87 \quad$ (1.1)

88 P.2: all right eh: ((reads aloud $))>$ I would like to specify that

89 I do not confess the attempted theft, $<>$ I admit the voluntary

$90 \quad$ damage. $<\S$

91 S.22: ${ }^{\circ}$ yes $^{\circ}$ 
92 P.2: so you are going to sign we are both going to sign there (0.3)

93 and then you a:re going $\mathrm{mmh}$ you are going to see a lawyer

After a silence (line 40), the prosecutor introduces the writing activity with a two-part transition token "all right (so)" (line 41) followed by a futureoriented metacommunicative formulation ("we we we are going to say," line 43). The prosecutor then verbalizes the first element of the written statement ("I admit the facts," lines 43-44), recycling utterances from talk in the prior activities that display not only how the prosecutor has understood the suspect's earlier statements but also his own institutional orientations for the work at hand. This verbalization of the written text is typically delivered in short segments that provide for the suspect to respond one way or another. However, despite the pauses in line 44, the suspect remains silent. Once this first element has been written on the hearing record form, the prosecutor proceeds to detail the facts in question. It is at this point (lines 44-45) that the prosecutor begins to interweave questions with the ongoing activity of writing the suspect's statement. By doing this, he reintroduces into the conversation, one by one, the facts mentioned earlier during the presentation of the charges. Until the end of the sequence (line 91), the writing of the statement, which seems to be the main activity, is continually interpenetrated by a second activity: questioning. These two activities both contribute elements to and reflexively constitute one another.

The first question introduced by the prosecutor, "what so er you broke in is that it" (lines 44-45), revoices the earlier assertion "you entered the apartment ... you broke a pane" (Excerpt 5a, lines 6-8) but now legally categorizes the acts the suspect is charged with. ${ }^{44}$ This question is open ended at the beginning ("what so er," line 44) but narrows along the way to submit for confirmation a description of the facts ("you broke in is that it," lines 44-45). Now the suspect produces agreement followed by mitigation ("yes well apparently," line 46), but the prosecutor proceeds rapidly to a new question about what the suspect's actions consisted of, ignoring the epistemic uncertainty in his response. Using different grammatical trajectories and self-corrections ("you have what did you do break," line 47), the prosecutor finally finishes his question about what the suspect did, using the term "break," a word that corresponds to the original charges in line 8 (Excerpt 5a) where the prosecutor said, "you broke a pane." The suspect finally declares a specific action, "I smashed a pane" (line 48), which can hold him accountable for the charge of "forcible entry." However, the suspect once again begins to downplay his admission ("according to what," 
line 48$)^{45}$ while the prosecutor interjects a repetition of the suspect's own admission (line 48), now in the voice of the second person ("you smashed a pane," line 49). This effectively sequentially deletes what was about to be a mitigation of the suspect's admission to the charge and with the addition of a confirmation requesting paralinguistic tag question ("eh?," line 49), also requires the suspect to align as a coparticipant in the writing activity. In addition, the prosecutor reinforces the primacy of the writing activity by repeating the admitted action - the suspect smashed a pane-although now transforming it into the first person ("I smashed a pane," line 51) as he writes it down on the hearing record form. Despite the suspect now offering to pay for the pane (lines 53-54), ${ }^{46}$ the prosecutor once again sequentially deletes the suspect's talk by reading back what he just wrote ("I smashed a pane," line 56).

The prosecutor next introduces a further element into the written statement ("and I entered the apartment," line 57) that repeats the earlier charges ("you entered the apartment," Excerpt 5a, line 6), transforming the "you" to "I." Without waiting for a confirming response from the suspect, the prosecutor then goes directly to a new question ("did you search around," lines 57-58), which alludes to an action that could possibly justify the earlier charge of attempted theft (Excerpt 5a, lines 5-6) that the suspect had already obliquely refused to admit to (Excerpt 5 b, lines $31-39$ ). The suspect denies having searched around (Excerpt 5c, line 59), and the prosecutor begins to verbalize and write the denial ("I did not," line 61). Nevertheless, the suspect continues his answer, giving a more detailed and "innocent" description of his actions inside the apartment ("as soon as I saw that it was occupied (bam) I wanted to leave," line 62). For a third time, the prosecutor sequentially deletes this added information when he completes his verbalization and writes "I did not search around" (lines 61-63). At this point, the prosecutor reviews aloud what he has written so far (lines 63-65), to which the suspect agrees ("yes," line 66). Now the prosecutor returns to questioning the facts of the case ("and so then so you were stopped," line 67), to which the suspect replies "yes the owner (arrived)" (line 69). Once again, the exchange echoes the original description of what happened produced during the presentation of the charges (Excerpt 5a, lines 10-16). ${ }^{47}$

Returning to the writing activity, the prosecutor now offers the suspect two options for describing the charges he is admitting to (lines 71-74). Both options are legal categories ("attempted theft" and "voluntary damage" ${ }^{48}$ ) relevant to the issues at stake in prosecuting the case: the precise nature of the suspect's acts and his intention in breaking the pane and entering 
the apartment. The suspect rejects the first option and chooses the second, employing the same terms used by the prosecutor ("voluntary damage," line 75). The prosecutor then resumes writing, first producing a formulation of the upcoming activity ("so I am going to write it down, line 76). Making it clear that the suspect has rejected the charge of attempted theft, the prosecutor verbalizes an attributed clarification and writes, "I would like to specify that I do not confess the attempted theft," lines 79-80). Only then does the prosecutor verbalize and write the admission of voluntary damage ("I admit the voluntary damage," line 81 ). What was said by the suspect in line 48 ("I smashed a pane") and what was written by the prosecutor in line 51 ("I smashed a pane") is now repackaged as "I admit the voluntary damage." The prosecutor next asks one final question: "You were drunk is that it?" (line 84), acknowledging earlier talk on this topic (Excerpt 5a, line 19, and Excerpt 5b, lines 23-28). Nevertheless, as I have shown throughout the discussion, the prosecutor focuses with this question only on one aspect of the suspect's talk; he refers only to the alcoholic intoxication and not any other possibility. In response, the suspect once again describes his state at the time he committed the alleged crime using the same complex terms as he used earlier ("drunk and under the effect of a I do not know any more what they call that," lines 85-86). However, neither intoxication nor being under the influence of an unspecified substance-circumstances that could recategorize the suspect's acts, explain or excuse them, or mitigate his responsibility-are included in the written statement. The prosecutor does not draw any element for inclusion in the text from this exchange. ${ }^{49}$ Finally, the prosecutor reads aloud what he had written on the hearing record form just before the exchange about intoxication ("I would like to specify that I do not confess the attempted theft, I admit the voluntary damage"; lines 88-90). To this, the suspect displays acceptance ("yes," line 91), and the prosecutor then moves to the closing phase of the hearing by asking the suspect for his signature and informing him of what will happen next.

As I have shown, the discussion of what happened and the writing of the suspect's statement, taken together, reflexively constitute each other through the plurality and entanglement of activities. Indeed, well before the writing begins, the discussion between the prosecutor and the suspect seems oriented to the final task of producing this written text. This is retrospectively observable, for instance, when the prosecutor composes the first element of the suspect's statement ("I admit the facts," lines 43-44) from the exchanges preceding the writing sequence. Thereafter, the discussion 
of the facts directs the drafting of the statement whose written elements followed from the various questions and answers. In turn, once the writing activity has begun, elements already on paper guide the remaining discussion, making new questions relevant. However, the extent to which talk and text interpenetrate and are reciprocally influenced depends largely on the prosecutor. As the person in charge of this hearing, he controls the transitions between different activities, selecting not only among questions and verbalizations as first parts of interactional exchanges but also designing the topical trajectories between turn types.

\section{PROSECUTOR'S ORIENTATIONS AND SUSPECT'S TALK}

As I have shown in Excerpt $5(\mathrm{a}-\mathrm{c})$, although the discussion is collaboratively achieved by both the prosecutor and the suspect, a closer examination reveals that it is the prosecutor who directs the trajectories at all moments of this institutional interaction. Structuring the entire encounter, he opens and closes the discussion, introduces and interweaves the different sequential activity types, and initiates the transition from one activity to another. To accomplish this, the prosecutor deploys a large range of turn types, including but not limited to elicitations of responses, questions, verbalizations in the voice of the suspect, and requests for confirmation, which are first parts of the exchanges within each activity type. Thus, the prosecutor is in an advantaged position to shape the discussion as a whole as well as the suspect's written statement so that they conform to the prosecutor's own orientations for establishing what happened.

These organizational resources are put in the service of transferring the elements of the charges throughout the different sequential activities into the suspect's written statement. The analysis has indicated that one of the most striking practices is the prosecutor's transposition of "you" statements to "I" statements; for instance, "you entered the apartment" in the presentation of the charges becomes "I entered the apartment" in the written statement. As I showed in Excerpt 5, the prosecutor introduces the charges at the start of the discussion, but the suspect does not elaborate on them until the prosecutor begins to question him and write down his statement. Changing and interweaving activities, the prosecutor progressively leads the suspect to talk about the acts he attributes to him and shapes not only the suspect's talk but his written statement as well. As the analysis 
shows, the prosecutor is able to do this smoothly, rapidly, and nonargumentatively. ${ }^{50}$ The hearing is meant to offer an opportunity for the suspect - if he so chooses - to have his perspective of the events recorded in written form, the suspect being strongly dependent on the prosecutor for this. Nevertheless, Excerpt 5 demonstrates that it is the prosecutor who in accordance with his own orientations, initiates and composes the writing of the statement, decides which of the suspect's words will be included or not and shapes each element comprising the written statement.

The elaboration of what happened and the written statement seem to be guided by a practical procedure common to the hearings in the corpus: establishing an "I"- - the first-person voice of the written statementmeant to represent the suspect. This "I" is both unifying and multiple in the sense that it brings together different orientations and has multiple dimensions-an "I" who is declarative, affirmative, accused, agentive, (perhaps) responsible, and endowed with intentions and motives. ${ }^{51}$ Once completed, the written statement composed in Excerpt 5 reads as follows: "I admit the facts. I smashed a pane and I entered the apartment. I did not search around. I would like to specify that I do not confess the attempted theft. I admit the voluntary damage." In this constructed text, the suspect, S.22, is portrayed as one who makes a statement, supports assertions about the facts, and expresses himself exclusively in relation to the offenses and acts with which he is charged. His textual persona appears to be accountable for actions that he may have committed for purposes that his statement makes explicitly or suggests. Besides being multiple, the "I" is also unifying because in a perfect example of judicial ventriloquism, the final written statement inserts the orientations of the judicial system displayed during the hearing into the constructed voice of the suspect. ${ }^{52}$

The prosecutor's orientations toward the elaboration of what happened are observable in the way the prosecutor introduces, selects, modifies, and rejects elements of the facts. In doing so, the prosecutor accomplishes several tasks specific to the judicial situation in progress-such as elucidating the facts, informing the suspect, and collecting the suspect's statements-while decidedly favoring the prosecution. The prosecutor focuses on those facts that justify the proceedings and emphasizes the most incriminating options and discards any mitigating elements. Thus, although the encounter appears to be a "you say, I write down" exchange in which the suspect makes a statement to a partner who simply transcribes, the discussion and the resulting written statement are in fact produced largely in accordance with the accusatory dimension of the prosecutor's work. 


\section{CONCLUSIONS}

In this study, I have analyzed the specifics of the actual conversational practices involved in the organization of a suspect's pretrial hearing in the French criminal system. Through different sequential activity types, connected and entangled, prosecutors and suspects reflexively constitute both a discussion about the facts of the case and the written text meant to represent the suspect's statement. Echoing the legal and institutionally ambiguous nature of the hearing, the interactional organization of this encounter combines the informing of the suspect, the writing down of his statements, the examination of the case facts, and the building of the accusatory case against the suspect. It is the recurring complex and flexible combination of these dimensions that enables the prosecutor to establish, in a nonadversarial encounter, the prosecutorial position against an arrested suspect. For once the hearing record form is signed by both parties, the suspect's legal status will change to that of defendant.

This article is meant to contribute to several current and well-established lines of research. The phenomena of plurality and entanglement of sequential activity types is of vital import for the study of extended sequences of conversation. ${ }^{53}$ In this analysis, I suggest that recurrently combining different sequential activity types in complex and flexible ways is an essential resource for accomplishing the multidimensional practicality of talk-in-interaction. Examining an instance of a routine institutional encounter, the analysis contributes as well to the study of the relation between the organization of talk and the accomplishment of work activities. ${ }^{54}$ Given the complex and ambiguous nature of the hearing I studied, the analysis makes relevant more than ever the importance for analysts to avoid an a priori characterization of any institutional interaction because to do so risks excessively narrowing the exploration of the data. ${ }^{55}$

My description of the actual practices that constitute a French pretrial criminal hearing also enriches the long-standing interest among ethnomethodologists in interactions in judicial settings. ${ }^{56}$ It opens to scrutiny accelerated continental judicial procedures and legal work activities in the pretrial phase, which are oriented to the writing of crucial documents that become part of the official record of the case. This connection between talk and documentation thus also links this study to research on the production of texts in the course of interaction. ${ }^{57}$ To examine the production of the reflexively coconstructed, organizational objects that are both talk and text, I have emphasized the importance of and interrelation between sequential, 
topical, practical, and institutional aspects of encounters in which a text is produced. By combining analyses of such phenomena, one can map out a fruitful and appropriate approach to the study of the locally managed and convergent accomplishment of text and talk.

\section{NOTES}

1 Throughout this article, the use of pronouns indicates the gender of the prosecutor and suspect.

2 Code de procédure pénale 1993-1994 [Code of criminal procedure 1993-1994] (1993, p. 451).

3 This article presents a study of a collection of 67 prosecutor-suspect judicial hearings conducted in the Paris Courthouse (France) within the framework of the French criminal procedure of comparution immédiate. I illustrate the findings of this larger study (González Martínez, 2000, 2001, 2003, 2005) mainly through the analysis of one encounter in particular.

4 This statement becomes part of a larger official document, the hearing record. In the first part of the document, after the details of the suspect's identity, the prosecutor writes the charges brought against the suspect. Then the record form reads "Advised that if he [the suspect] should so request we would take his statement, the defendant responded:." It is here, in a blank space of about a dozen lines, where the prosecutor writes the suspect's statement. At the end of the form, there is a place for the suspect and the prosecutor to sign, following the statement, "After reading the above, the defendant signed with us."

5 Docile record is a term that Lynch (1985) borrowed from Garfinkel (see Garfinkel, 1967, and Garfinkel, Lynch, \& Livingston, 1981).

6 On the production of the objectivity of reality via documents, see Cicourel (1968), Smith (1974), and Zimmerman (1969).

7 Komter (2001, 2002), Linnell and Jönsson (1991), and Rock (2001) have analyzed the production of similar texts.

8 I drew this material from audiovisual recordings (film rushes) made by internationally renowned French documentary filmmaker Raymond Depardon for Délits flagrants (Caught in the act; Depardon, 1994). A major figure in the Cinéma Direct movement, Depardon uses recording methods (camera on a tripod, fixed angles, uninterrupted long sequence-length shots) to capture naturally occurring courses of action in different contexts.

9 This room measures some $110 \mathrm{ft}^{2}$ and has two doors opposite each other. The prosecutor sits at his desk, with one of the doors to his back, and the suspect is seated facing him or her. 
10 At the time of the recordings, the suspect had the right to speak to an attorney after his or her 20th hr in custody. French law does not provide for the presence of counsel during the pretrial hearing. After this hearing and just before appearing in court, the suspect, hereafter known as the defendant (prévenu), may meet with a lawyer (often a public defender) if he or she so wishes.

11 At the time of the recordings, no equivalent of plea bargaining existed in France. The case is always fully examined by the court, even when the suspect has accepted the charges during his or her interview with the prosecutor. The court, composed of three judges, questions the defendant, hears the prosecutor and defense speeches, and renders the judgment.

12 Since the time of the recordings, the scope of the immediate trial procedure has been extended to offenses punishable by a maximum imprisonment of 6 months to 10 years.

13 Lévy $(1984,1987)$ has studied the historical evolution and application of French accelerated criminal procedures.

14 Moreover, cases are regularly handled through this accelerated procedure when the prosecutor has no guarantees that the suspect, if released prior to trial, will attend court at a later date (e.g., the suspect has no home, job, or family). Rather than keeping the suspect in custody until the hearing date, the prosecutor sends him or her to trial immediately.

15 Of the 83 hearings recorded by Depardon (1994), the case files going to some sort of trial are color coded. A pink case file indicates that the prosecutor is ready to send the case to an immediate trial. In only two cases did the prosecutor change his decision. Two additional cases were dismissed, and 12 cases, whose files were green, were prosecuted through a different criminal procedure. This analysis is based on the remaining 67 cases.

16 For debate over the legal nature of the prosecutor's actions and the distinction between legal categorization and the actual powers conferred, see Stefani, Levasseur, and Bouloc (1963/1993). In the recordings, the prosecutor refers to these interviews as "hearings," but outside the room where the interviews takes place, a sign reads "Interrogation in progress. Do not disturb." During the hearings, suspects seem not to understand the role of their interlocutor. Some suspects ask, "And the prosecutor, will I see him today?"; or "What kind of sentence are you going to give me?" When leaving the hearings, some suspects thank the prosecutor or attempt to shake his or her hand, to which the prosecutor responds that "This is not exactly a friendly situation" or that he does not know if he should be thanked. In professional and journalistic accounts, the suspect is referred to as the "accused," the "guilty," or the "offender"; the prosecutor is referred to as the "judge" or the "investigating magistrate"; the meeting is referred to variously as the "hearing," the "interrogation," the "interview," or the "notification."

17 The extent to which the prosecutor verbalizes, reads, or summarizes the statement varies greatly; in some cases, he or she simply hands the completed hearing record to the suspect, requesting his or her signature. The suspect usually signs the record without explicitly requesting that certain elements be integrated into the statement, without ask- 
ing questions about its content, and even, apparently, without taking the time to read it carefully.

18 The statement is a piece of evidence like any other that may be contested later by the defense, the prosecutor, or the judges. In theory, the court may find the suspect not guilty even when he or she accepts the charges.

19 In ethnomethodological literature — see, for example, Turner $(1970 / 1971,1972)$ - the term activity is used to refer to different levels of interactional conduct: an action achieved in a turn or several turns of speech (e.g., a complaint during a discussion), the type of situation (e.g., a group-therapy session), and the practices that produce the course of action (e.g., a story-telling sequence).

20 For further discussion of the plurality and entanglement of sequential activities, see González Martínez (2003).

21 Turn preallocation (Sacks, Schegloff, \& Jefferson, 1974) and turn-type preallocation (Atkinson \& Drew, 1979) are considered distinctive characteristics of formal (Atkinson, 1982) and institutional (Drew \& Heritage, 1992) interactions.

22 As emphasized in the literature (Eglin \& Wideman, 1986; Maynard 1991; ten Have, 1991; Watson, 1986), asymmetry between interlocutors needs to be established through a careful turn-by-turn analysis of their interaction and not merely by reference to the larger institutional positions they occupy.

23 I use the conversational notion of "orientations," which stresses observable practices, rather than the more cognitive or epistemic terms of relevancies or perspectives to refer to the way interlocutors orient themselves in situ to the various dimensions of an interaction. For further discussion, see González Martínez (2003).

24 The hearing takes place without the prosecutor explaining to the suspect what its purpose is or how it will proceed, except by sporadically using formulations such as "wait first you are going to listen to me" or "I will then take down your statement."

25 What follows is only a brief introduction to these four sequences. For further discussion, see González Martínez (2003).

26 Rather than asking the suspect to confess or explain himself or herself, the prosecutor invites him or her to make a statement.

27 On these pairs, see Atkinson \& Drew (1979) and Komter (1994, 1998).

28 The organization of these sequences is similar to the production of invited stories (Cuff \& Francis, 1978; Watson, 1990), second stories, and series of stories (Sacks, 1974, 1978, 1992; Jefferson, 1978a; Ryave, 1978).

29 The excerpts in this article are translations from the French, which preserve as much as possible the syntactic organization of the original utterances. This may result in some oddities for written English. See the Appendix for the French transcripts. All transcriptions conventions follow Jefferson (2004) except for those listed at the beginning of the Appendix. 
30 The notation identifies the corpus data (Délits Flagrants corpus) and speakers: prosecutor (Prosecutor no. 2), and suspect (Suspect no. 62); D stands for the French déféré.

31 The translation of reproché with "blamed" takes account of the prosecutor's predominant use, throughout the hearing, of the terms reproche or reprocher in place of accusation or accuser, which are reserved for the hearing in court.

32 During the presentation of charges + response sequence, unmodulated other-corrections (Schegloff, Jefferson, \& Sacks, 1977/1990) are very frequent. Schegloff et al. $(1977 / 1990$, p. 53) noticed that one environment in which other-correction is used is the storytelling sequence as a vehicle for the recipient of the story to become a co-teller. In this data, these corrections, often related to minor details of a description in progress, display the corrector's "entitlement to tell."

33 For a discussion of what counts as a question and on question-answer series, see Conein (1987), Heritage and Roth (1995), Levinson (1979), McHoul (1987), Sacks (1992), and Schegloff (1976/ 1984); in judicial settings, see Atkinson and Drew (1979) and Lynch and Bogen (1996).

34 Coulter (1990), M. H. Goodwin (1990), M. H. Goodwin and Goodwin (1987), Hutchby (1996), Lynch (1982), and Maynard (1985) have described sequences with similar features.

35 "La Cité" is the popular name for the main Paris police headquarters.

36 On formulations, see Garfinkel and Sacks (1969/1986) and Heritage and Watson (1979, 1980).

37 The organization of activity entanglement, described in detail in González Martínez (2003), includes among other phenomena activity transitions (Jacoby, 1998), presequences (Sacks, 1992; Schegloff, 1980), activity changes (Schegloff, 1988-1989; Whalen, Zimmerman, \& Whalen, 1988), openwork (ajours; González Martínez, 2001), side sequences (Jefferson, 1972), insertion sequences (Schegloff, 1972), expanded sequences (Jefferson \& Schenkein, 1977/1978), and activity contamination (Jefferson \& Lee, 1981/1992).

38 On the institutional we, see Sacks (1992, I, pp. 568-577).

39 As in this excerpt, the presentation of the charges sometimes presents an openwork organization (ajours; González Martínez, 2001). The prosecutor creates small spaces in his long turn for the suspect to express his views. The suspect's talk is nevertheless strictly controlled by the prosecutor who seems to be seeking only short utterances, preferably agreements, in return (see Excerpt 1, lines 1-9, and Excerpt 5a, lines 5-12, for a comparison of what happens when the suspect disagrees at this point). Therefore, the prosecutor's turn is simultaneously and equivocally oriented to informing the suspect, who is expected to listen, to requesting his agreement with the charges, and to subtly gleaning the suspects orientations to the facts of the case.

40 C. Goodwin (1986), Jefferson (1978b, 1984), Pomerantz (1984), Sacks (1992), and Schegloff (1982) have discussed the importance and multivocality of these tokens. 
41 See Note 32 for this type of correction.

42 The repair therefore operates as a side sequence (Jefferson, 1972).

43 "[Q]u'est-ce que vous allez à dire?" is the French original. The prosecutor seems at first to use the construction "qu'est-ce que vous allez dire?" ("what are you going to say?" [after this in court?]), but switches halfway to "qu'est-ce que vous avez à dire?" ("what do you have to say?" [here and now?]).

44 "Entrée par effraction" (forcible entry) in the French original.

45 The mitigated agreements in lines 46 and 48 reinforce the equivocality of the suspect's "yes" responses during the presentation of the charges (lines, 7, 9, and 11 in Excerpt 5a).

46 It is not clear from the data who "Mister (LN...)" is. In case the suspect is referring to the owner of the apartment, the assertion would back the suspect's earlier claim that he met the owner (Excerpt 5a, lines 13-16). However, the suspect may alternatively be referring to someone else-for example, as is often the case for these restitution offers, the policeman in charge of the case.

47 During the presentation of charges, the suspect corrects the prosecutor concerning the identity of the person who happened on him inside the apartment ("it is not the neighbor it is the owner," Excerpt 5a, line 13). In Excerpt 5c, line 67, the prosecutor skips this aspect of the facts, whereas the suspect again refers to the owner ("the owner (arrived),"line 69).

48 Note that the prosecutor does not consider "involuntary damage" as an option.

49 On the recording, there are no sounds of writing additional elements without verbalizing them.

50 In contrast to prosecutor P. 2 in the discussions conducted by other prosecutors in the corpus, I observe numerous dispute sequences as I described previously (Excerpt 3).

51 For a description of this practical procedure underlying the hearings, see González Martínez (2000, 2003).

52 This would account for the two negative sentences in suspect S.22's statement that encode descriptions of the facts that are opposed to those voiced by the suspect himself. This entanglement of orientations is also related to the sometimes enigmatic or convoluted phrasing of the written statements resulting from these hearings. See also Drew's (1992) discussion of the production of enigmas by a defense attorney during a crossexamination.

53 See Schegloff $(1990,1995)$.

54 See Drew \& Heritage (1992).

55 Watson (1995) argued against an a priori or monolithic characterization of the course of action that would not correspond to the orientations of the participants. See also Schegloff (1992). 
56 For recent reviews of the literature, see Travers and Manzo (1997) and Travers (2001).

57 See Mondada (2005), Psathas (1990), and Zimmerman (1992).

\section{REFERENCES}

Atkinson, J. M. (1982). Understanding formality. The categorization and production of "formal interaction." The British Journal of Sociology, 33, 86-117.

Atkinson, J. M., \& Drew, P. (1979). Order in court. The organization of verbal interaction in judicial settings. London: Macmillan.

Cicourel, A. V. (1968). The social organization of juvenile justice. New York: Wiley.

Code de procédure pénale 1993-1994 [Code of criminal procedure 1993-1994] (1993). Paris: Dalloz.

Conein, B. (1987). Quelques formes de l'interprétation de la conversation dans la conversation [Some forms of interpretation of the conversation during the conversation]. Lexique, 5, 37-64.

Coulter, J. (1990). Elementary properties of argument sequences. In G. Psathas (Ed.), Interaction competence (pp. 181-203). Lanham, MD: University Press of America.

Cuff, E. C., \& Francis, D. W. (1978). Some features of "invited stories." About marriage breakdown. International Journal of the Sociology of Language, 18, 111-133.

Depardon, R. (1994). Délits flagrants [Caught in the act] [Motion picture]. France: Palmeraie et désert/La Sept Cinéma

Drew, P. (1992). Contested evidence in courtroom cross-examination. The case of a trial for rape. In P. Drew \& J. Heritage (Eds.), Talk at work: Interaction in institutional settings (pp. 470-520). Cambridge, England: Cambridge University Press.

Drew, P., \& Heritage, J. (Eds.). (1992). Talk at work: Interaction in institutional settings. Cambridge, England: Cambridge University Press.

Eglin, P., \& Wideman, D. (1986). Inequality in professional service encounters. Verbal strategies of control versus task performance in calls to the police. Zeitschrift fur Soziologie, 15, 341-362.

Garfinkel, H. (1967). Studies in ethnomethodology. Englewood Cliffs, NJ: Prentice Hall.

Garfinkel, H., Lynch, M., \& Livingston, E. (1981). The work of a discovering science construed with materials from the optically discovered pulsar. Philosophy of the Social Sciences, 11, 131-158.

Garfinkel, H., \& Sacks, H. (1986). On formal structures of practical actions. In H. Garfinkel (Ed.), Ethnomethodological studies of work (pp. 160-193). London: Routledge \& Kegan Paul. (Original work published 1969)

González Martínez, E. (2000). La "déclaration" dans le cadre d'une procédure pénale ou la constitution d'un "je" multiple et rassembleur [The "statement" in the context of criminal proceedings or the constitution of a multiple and unifying "I"]. Revue Suisse de Sociologie, 26, 591-614.

González Martínez, E. (2001). Comment agir en confiance avec un partenaire dont on se méfie? [How can one trust a partner of whom one is suspicious?]. Réseaux, 19, 87-123. 
González Martínez, E. (2003). L'audition de comparution immédiate. L'organisation des échanges langagiers [The organization of talk in "immediate trial" hearings]. Unpublished doctoral dissertation. Paris: Université de Lausanne/Ecole des hautes études en sciences sociales.

González Martínez, E. (2005). Organisation et accountability de l'audition de comparution immédiate [Organization and accountability of the "immediate trial" hearing]. Réseaux, 129-130, 209-241.

Goodwin, C. (1986). Between and within. Alternative sequential treatments of continuers. Human Studies, 9, 205-217.

Goodwin, M. H. (1990). He-said-she-said. Talk as social organization among black children. Bloomington: Indiana University press.

Goodwin, M. H., \& Goodwin, C. (1987). Children's arguing. In S. U. Philips, S. Steele, \& C. Tanz (Eds.), Language, gender and sex in comparative perspective (pp. 200-248). Cambridge, England: Cambridge University Press.

Heritage, J., \& Roth, A. (1995). Grammar and institution. Questions and questioning in the broadcast news interview. Research on Language and Social Interaction, 28, 1-60.

Heritage, J., \& Watson, D. R. (1979). Formulations as conversational objects. In G. Psathas (Ed.), Everyday language. Studies in ethnomethodology (pp. 123-162). New York: Irvington.

Heritage, J., \& Watson, D. R. (1980). Aspects of the properties of formulations in natural conversations. Some instances analyzed. Semiotica, 30, 245-262.

Hutchby, I. (1996). Confrontation talk. Arguments, asymmetries and power on talk radio. Mahwah, NJ: Lawrence Erlbaum Associates, Inc.

Jacoby, S. (1998). Science as performance. Socializing scientific discourse through the conference talk rehearsal. Unpublished doctoral dissertation, University of California, Los Angeles.

Jefferson, G. (1972). Side sequences. In D. Sudnow (Ed.), Studies in social interaction (pp. 294-338). New York: Free Press.

Jefferson, G. (1978a). Sequential aspects of storytelling in conversation. In J. Schenkein (Ed.), Studies on the organization of conversational interaction (pp. 219-248). New York: Academic.

Jefferson, G. (1978b). What's in a "Nyem"?. Sociology, 12, 135-139.

Jefferson, G. (1984). Notes on a systematic deployment of the acknowledgment tokens "Yeah" and "Mm hm." Papers in Linguistics, 17, 197-216.

Jefferson, G. (2004). Glossary of transcript symbols with an introduction. In G. H. Lerner (Ed.), Conversation analysis. Studies from the first generation (pp. 13-31). Amsterdam: Benjamins.

Jefferson, G., \& Lee, J. R. E. (1992). The rejection of advice. Managing the problematic convergence of a "troubles-telling" and a "service encounter." In P. Drew \& J. Heritage (Eds.), Talk at work: Interaction in institutional settings (pp. 521-548). Cambridge, England: Cambridge University Press. (Original work published 1981)

Jefferson, G., \& Schenkein, J. (1978). Some sequential negotiations in conversation. Unexpanded and expanded versions of projected action sequences. In J. Schenkein (Ed.), Studies on the organization of conversational interaction (pp. 155-172). New York: Academic. (Original work published 1977)

Komter, M. L. (1994). Accusations and defenses in courtroom interaction. Discourse and Society, 5, 165-187. 
Komter, M. L. (1998). Dilemmas in the courtroom. A study of trials of violent crime in the Netherlands. Mahwah, NJ: Lawrence Erlbaum Associates, Inc.

Komter, M. L. (2001). La construction de la preuve dans un interrogatoire de police [The construction of evidence in a police interrogation]. Droit et Société, 48, 367-393.

Komter, M. L. (2002). The suspect's own words. The treatment of written statements in Dutch courtrooms. Journal of Forensic Linguistics, 9, 168-192.

Levinson, S. C. (1979). Activity types and language. Linguistics, 17, 365-399.

Lévy, R. (1984). Pratiques policières et processus pénal. Le flagrant délit [Police's practices and penal process. The flagrante delicto]. Paris: Centre de recherches sociologiques sur le droit et les institutions pénales.

Lévy, R. (1987). Du suspect au coupable. Le travail de police judiciaire [From the suspect to the guilty. The work of the judicial police]. Paris: Méridiens Klincksieck.

Linell, P., \& Jönsson, L. (1991). Suspect stories. Perspective-setting in an asymmetrical situation. In I. Marková \& K. Foppa (Eds.), Asymmetries in dialogue (pp. 75-100). Hemel Hempstead, England: Harvester Wheatsheaf.

Lynch, M. (1982). Closure and disclosure in pre-trial arguments. Human Studies, 5, 285-318.

Lynch, M. (1985). Discipline and the material form of images. An analysis of scientific visibility. Social Studies of Science, 15, 37-66.

Lynch, M., \& Bogen, D. (1996). The spectacle of history. Speech, text and memory at the Iran-Contra-hearings. Durham, NC: Duke University Press.

Maynard, D. W. (1985). How children start arguments. Language in Society, 14, 1-29.

Maynard, D. W. (1991). Interaction and asymmetry in clinical discourse. American Journal of Sociology, 97, 448-495.

McHoul, A. W. (1987). Why there are no guarantees for interrogators. Journal of Pragmatics, 11, 455-471.

Mondada, L. (2005). "Il faut d'abord ramasser les arguments." La coordination de la parole-en-interaction et de l'inscription dans l'élaboration collective des topics ["First we should pick up the arguments." Coordination of talk-in-interaction and inscription in the collective elaboration of topics]. In R. Bouchard \& L. Mondada (Eds.), Les processus de la rédaction collaborative (pp. 131-164). Paris: L'Harmattan.

Pomerantz, A. (1984). Agreeing and disagreeing with assessments. Some features of preferred/dispreferred turn shapes. In J. M. Atkinson \& J. Heritage (Eds.), Structures of social action: Studies in conversational analysis (pp. 57-101). Cambridge, England: Cambridge University Press.

Psathas, G. (1990). The organization of talk, gaze and activity in a medical interview. In G. Psathas (Ed.), Interaction competence (pp. 205-230). Lanham, MD: University Press of America.

Rock, F. (2001). The genesis of a witness statement. Forensic Linguistics, 8, 44-72.

Ryave, A. L. (1978). On the achievement of a series of stories. In J. Schenkein (Ed.), Studies on the organization of conversational interaction (pp. 113-132). New York: Academic.

Sacks, H. (1974). An analysis of the course of a joke's telling in conversation. In R. Bauman \& J. Sherzer (Eds.), Explorations in the ethnography of speaking (pp. 337-353). Cambridge, England: Cambridge University Press. 
Sacks, H. (1978). Some technical considerations of a dirty joke. In J. Schenkein (Ed.), Studies on the organization of conversational interaction (pp. 249-269). New York: Academic.

Sacks, H. (1992). Lectures on conversation: I-II. Oxford, England: Blackwell.

Sacks, H., Schegloff, E. A., \& Jefferson, G. (1974). A simplest systematics for the organization of turn-taking for conversation. Language, 50, 696-735.

Schegloff, E. A. (1972). Notes on a conversational practice: Formulating place. In D. Sudnow (Ed.), Studies in social interaction (pp. 75-119). New York: Free Press.

Schegloff, E. A. (1980). Preliminaries to preliminaries: "Can I ask you a question?." Sociological Inquiry, 50, 104-152.

Schegloff, E. A. (1982). Discourse as an interactional achievement. Some uses of "uh huh" and other things that come between sentences. In D. Tannen (Ed.), Analyzing discourse: Text and talk (pp. 71-93). Washington, DC: Georgetown University Press.

Schegloff, E. A. (1984). On some questions and ambiguities in conversation. In J. M. Atkinson \& J. Heritage (Eds.), Structures of social action: Studies in conversation analysis (pp. 28-52). Cambridge, England: Cambridge University Press. (Original work published 1976)

Schegloff, E. A. (1988-1989). From interview to confrontation. Observations of the Bush/ Rather encounter. Research on Language and Social Interaction, 22, 215-240.

Schegloff, E. A. (1990). On the organization of sequences as a source of "coherence" in talk-in-interaction. In B. Dorval (Ed.), Conversational organization and its development (pp. 51-77). Norwood, NJ: Ablex.

Schegloff, E. A. (1992). On talk and its institutional occasions. In P. Drew \& J. Heritage (Eds.), Talk at work: Interaction in institutional settings (pp. 101-134). Cambridge, England: Cambridge University Press.

Schegloff, E. A. (1995). Discourse as an interactional achievement: III. The omnirelevance of action. Research on Language and Social Interaction, 28, 185-211.

Schegloff, E. A., Jefferson, G., \& Sacks, H. (1990). The preference for self-correction in the organization of repair in conversation. In G. Psathas (Ed.), Interaction competence (pp. 31-61). Lanham, MD: University Press of America. (Original work published 1977)

Smith, D. (1974). The social construction of documentary reality. Sociological Inquiry, 44, 257-268.

Stefani, G., Levasseur, G., \& Bouloc, B. (1993). Procédure pénale [Criminal procedure]. Paris: Dalloz. (Original work published 1964)

ten Have, P. (1991). Talk and institutions. A reconsideration of the "asymmetry" of doctor-patient interaction. In D. Boden \& D. H. Zimmerman (Eds.), Talk and social structure: Studies in ethnomethodology and conversation analysis (pp. 138-163). Cambridge, England: Polity.

Travers, M. (2001). Ethnométhodologie, analyse de conversation et droit [Ethnomethodology, conversation analysis and law]. Droit et Société, 48, 349-366.

Travers, M., \& Manzo, J. F. (Eds.). (1997). Law in action. Ethnomethodological and conversation analytic approaches to law. Aldershot, England: Dartmouth.

Turner, R. (1971). Words, utterances and activities. In J. D. Douglas (Ed.), Understanding everyday life: Toward the reconstruction of sociological knowledge (pp. 169-187). London: Routledge \& Kegan Paul. (Original work published 1970) 
Turner, R. (1972). Some formal properties of therapy talk. In D. Sudnow (Ed.), Studies in social interaction (pp. 367-396). New York: Free Press.

Watson, D. R. (1986). Doing the organization's work: An examination of aspects of the operation of a crisis intervention center. In S. Fisher \& A. Dundas Todd (Eds.), Discourse and institutional authority: Medicine, education and law (pp. 91-120). Norwood, NJ: Ablex.

Watson, D. R. (1990). Some features of the elicitation of confessions in murder interrogations. In G. Psathas (Ed.), Interaction competence (pp. 263-296). Lanham, MD: University Press of America.

Watson, D. R. (1995). Some potentialities and pitfalls in the analysis of process and personal change in counselling and therapeutic interaction. In J. Siegfried (Ed.), Therapeutic and everyday discourse as behavior change: Towards a micro-analysis in psychotherapy process research (pp. 301-339). Norwood, NJ: Ablex.

Whalen, J., Zimmerman, D. H., \& Whalen, M. R. (1988). When words fail. A single case analysis. Social Problems, 35, 335-362.

Zimmerman, D. H. (1969). Record-keeping and the intake process in a public welfare agency. In S. Wheeler (Ed.), On record: Files and dossiers in American life (pp. 319-354). New York: Russell Sage Foundation.

Zimmerman, D. H. (1992). The interactional organization of calls for emergency assistance. In P. Drew \& J. Heritage (Eds.), Talk at work: Interaction in institutional settings (pp. 418-469). Cambridge, England: Cambridge University Press.

\section{APPENDIX}

\section{Transcription Conventions}

P. (followed by an identification number) prosecutor

S./D. (followed by an identification number) suspect

(d...) talk not transcribed for reasons of confidentiality; $\mathrm{d} / \mathrm{j}=$ day; $\mathrm{M} / \mathrm{m}=$ month; $\mathrm{y} / \mathrm{a}=$ year; $\mathrm{LN} / \mathrm{N}=$ last name; $\mathrm{P} / \mathrm{L}=$ place (city, metro stop, train station, neighborhood).

$\S \quad$ end of the phenomenon

(...) turn continues

Excerpt 1 DF/P. 2-D. 62 (French original version)

01 P.2: $\quad>\underline{\text { alors }}<(0.9)$ ce qui vous est reproché c'est (.) ((feuillette

02 le dossier)) euh de voler un portefe:uille,

03 (.)

04 D.62: pas volé du tout

$05 \quad(0.5)$

06 P.2: attendez. (.) vous allez m'écouter 
07 D.62: ouais [pardon

08 P.2: [et après ensuite vous me direz ce que e vous en pensez

09 D.62: [(en) plus

10 P.2: [d'une part donc (0.4) euh:: (.) de voler euh: mmh un

11 portefeuille dans le RER, (0.7) et et et d'autre part alors que

12 vous êtes interdit du territoire français par deux décisions du

13 tribunal de (L...) $(0.7)$ du (j...m.......) et du (j...m.......) (0.3) hein?

14 interdiction de dix ans, interdiction de cinq ans, (0.5) de rester

15 en France (.) alors pour le vol (.) je vous écoute

$16 \quad(0.4)$

17 D.62: oui pour le vol (0.5) on est monté (0.5) faire (0.5) métro (L1 ...)

(1.1) on a acheté des tickets j'ai les tickets sur moi (1.5) j'ai pris le RER (.) pour aller au (L2 ...). (1.4) pour prendre (0.3) direction (0.3) (L3...) au métro. (0.4) parce que j'habite juste à (L4...) (0.9) et ben en montant (0.8) en montant (0.2) les: le RER pou:r (0.2) prendre le métro (0.5) parce que je veux sortir du RER (0.3) marcher un petit peu pour prendre le métro $(0.5)$ là je vois les flics

(0.6)

P.2: $\quad$ les policiers

D.62: les policiers (1.0) sauter dessus (1.2) ils m'ont fouillé et ils m'ont dit portefeuille portefeuille (0.3) j'ai dit j'ai rien sur moi,vous pouvez me fouiller (0.5) j'ai levé mes mains (0.7) et (elles) i ils m'ont fouillé (0.5) ils m'ont fouillé et tout $(0.3)$ après ils m'ont dit (0.6) s'il vous plaît (.) il faut que vous veniez avec moi (.) au poste (0.8) et j'ai accepté aller avec eux

\section{Excerpt 2 DF/P. 2-D. 82 (French original version)}

01 P.2: [quand vous dites, on a pris le sac vous étiez tous les deux?,

$02 \quad(1.9)$

03 D.82: oui! lui il a pris le sac moi j'étais avec lui hein! (0.7)

$04 \quad$ j'étais dehors mais je l'ai vu sortai: il y avait il y avait le sac

$05 \quad$ (1.9)

06 P.2: et pourquoi vous avez volé?

$07 \quad(0.9)$

08 D.82: ${ }^{\circ}$ parce que ça nous tendait les bras. ${ }^{\circ}$

$09 \quad(1.1)$

10 P.2: $\quad{ }^{\circ} c^{\prime}$ est trop facile c'est pour ça?

11 D.82: ${ }^{\circ}$ ouais $^{\circ}$ (1.8) ((P.2 feuillette le dossier $)$ ) et en plus euh je me tiens tranquille hein! depuis longtemps hein

14 P.2: vous avez brisé la vitrine?

15 D.82: non. 
$16 \quad(1.5)$

17 P.2: et lui?

$18 \quad(0.2)$

19 D.82: non. ça je peux vous le confirmer hein

Excerpt 3 DF/P. 1-D. 35 (French original version)

01 P.1: c'était pas un policier ce monsieur vous avez cru=

02 D.35: [moi ( )

03 P.1: =[qu'il travaillait (.) avec la police mais c'était pas un

04 policier

05 D.35: non c'est pas un policier mais il travaille avec eux! [parce que

06 P.1: [(enfin) il travaille avec (eux) il dit que hein?

07 D.35: non mais j'ai: j'étais avec lui une fois (.) à la:: Cité (0.2) il

08 est rentré moi j'ai resté dehors

09 P.1: tout le monde peut rentrer à la Cité: pour chercher des papiers

10 ou autre chose je veux dire il faut pas [( )

11 D.35: [mais il a une carte euh carte de visite qui est écrit: le numéro

12 de télépho:ne et des fois il parle avec un policier au téléphone

13 P.1: vous savez pas qui est au bout du fil je veux dire cette histoire

14 de policier il vous l'a peut-être fait croire >enfin< peu importe (...)

Excerpt 4 DF/P. 2-D. 62 (French original version)

01 P.2: >alors< d'après vous donc $(0.2)$ euh on va mettre ((oralise en

02 écrivant)) je (.) n'ai (1.1) commis (1.5) aucun vol§

$03 \quad(0.4)$

04 D.62: ouais

$05 \quad(3.1)$

06 P.2: $>$ alors < (.) ((oralise en écrivant)) je voulais: (1.8) voler: (0.8)

07 mais (1.5) je (.) n'ai (0.8) même (0.9) pas (.) commencé (5.0)

$08 \quad$ à commettre (1.6) le délit§ c'est ça?

$09 \quad(0.4)$

10 D.62: ' ${ }^{\circ}$ 'est ça mais c'est vrai ${ }^{\circ}$

$11 \quad(0.3)$

12 P.2: bon ça c'est pour le vol c'est votre déclaration (0.2) alors

13 maintenant $(\ldots)$

\section{Excerpt 5 DF/P. 2-D. 22 (French original version)}

01 D.22: =[je suis suivi: euh par le: (1.1) le médecin (N...) (je vois) (0.4)

$02>\mathrm{j}$ 'avais rendez-vous aujourd'hui en plus avec lui< le rhumatologue.

$03 \quad$ (1.5) pour ça justement

$04 \quad(1.0)$ 
05 P.2: alors ce que (0.2) nous vous reprochons c'est d'avoir tenté: $>$ de

$06 \quad \overline{\text { voler }}<(0.6)$ dans un appartement vous êtes rentré dans

07 l'appartement:,

08 D.22: oui

09 P.2: hein? vous avez brisé une vitre

10 D.22: oui

11 P.2: finalement un voisin est arrivé=

12 D.22: =oui=

13 P.2: =et et et et vous avez été arrêté alors [qu'est-ce que s'est

14 D.22: [non c'est pas le voisin c'est le propriétaire qui est arrivé

$15 \quad(0.9)$

16 P.2: ((feuillette le dossier $))$ c'est le propriétaire?=

17 D.22: =oui

18 P.2: et alors? qu'est-ce que vous allez:: à di::re?

19 D.22: ben rien $>c$ 'est ma faute je suis coupable c'est tout hein< eh eh! je sais bien que $\mathrm{j}$ aurais pas dû boire et pas prendre de: $(0.2){ }^{\circ}$ je sais pas comment il appelle ça un truc euh:: ${ }^{\circ}$, $(0.7)$

P.2: vous aviez bu quoi de l'alcool [du vin?,

D.22: [de l'alcool

$(0.2)$

P.2: $\quad$ hein?=

D.22: =le vin j'ai horreur de ça. un mélange de bière whisky et=

P.2: $=a h$ !

D.22: un petit comprimé je sais pas ce que c'était

(1.4)

P.2: bon vous vouliez voler: ou:?

D.22: >je je sais pas je peux pas vous dire (j'ai) aucune idée $<$ j'étais sous l'effet du: sous >et même (regarde) je savais même pas que j'étais au poste de police d'ailleurs<

D.22: =>je sais plus c'est ce comprimé qui m'a donné< c'est pas un comprimé c'est un truc plat $(0.8)$ c'est comme une feuille de papier qu'on ( )

(1.1)

P.2: $\quad$ bon $[($ alors $)$

D.22: $\overline{[(\text { ) })}$

P.2: $\quad$ vous on on on va dire $(($ oralise en écrivant $))<$ je reconnais $>(2.1)$ $<$ les faits:>§ (2.0) euh: mmh qu'est-ce que donc euh > vous êtes rentré par effraction c'est ça?<

D.22: oui ben apparemment $=$

P.2: =vous avez $>$ qu' est-ce que vous avez fait brisé? $<=$

P.2: $\quad=>$ vous avez cassé une [vitre hein?<

50 D.22: [(le monsieur). 


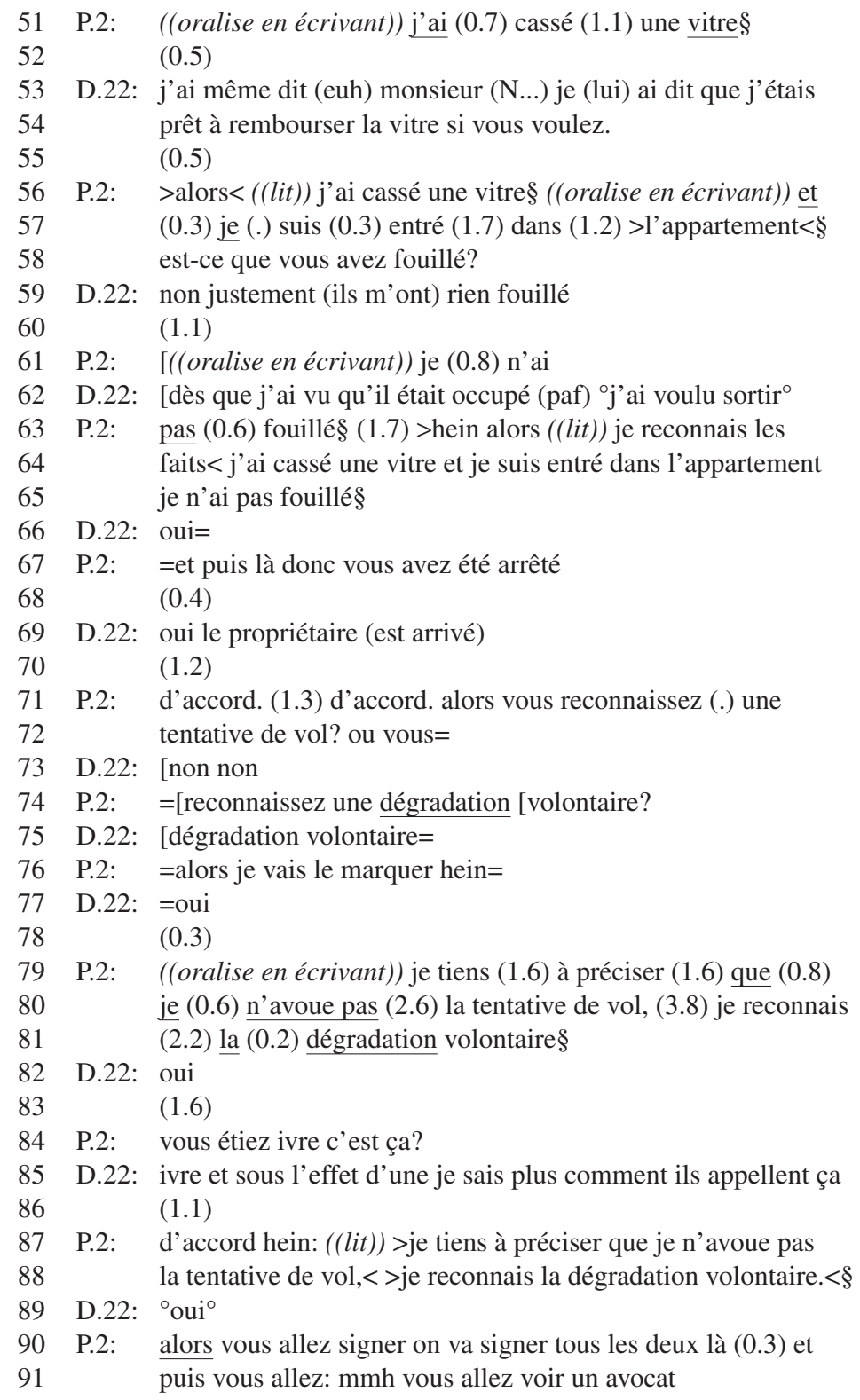

